\title{
Mental Mapping: Viewing the School Environment of the Mind
}

\author{
Fatiya Rosyida \\ Department of Geography, Universitas Negeri Malang \\ Malang, Jawa Timur, Indonesia \\ Corresponding email: fatiya.rosyida.fis@um.ac.id \\ Wakhidatus Sholikhah \\ Blitar, Jawa Timur, Indonesia \\ Ulfi Andrian Sari \\ Department of Geography, Universitas Kanjuruhan Malang \\ Malang, Jawa Timur, Indonesia
}

\begin{abstract}
One of the geographic curriculum learning objectives in 2013 is to comprehend spatial patterns, environmental and territorial, as well as the processes related to geosphere symptoms in both national and global context. One of the tools that can be used to determine the comprehension of spatial patterns is by using a mental map. A mental map is an individual's cognitive ability to describe the spatial information in their mind. A mental map is not only a way to understand the spatial patterns, but also an indicator to measure how well the students understand the characteristics of their environment. Good understanding of environmental characteristics through observation and analysis will help them in problem solving and decision making. Therefore, the mental map is an important basic ability in which students should possess. This capability is not only used on the subjects of geography but also in other subjects related to spatial information. Deeper study of students' mental map is crucial for further study. This is because the mental map can be used as a reference in determining methods and strategies in the next geography lesson. This study is a survey research. The survey was conducted in SMAN 1 Kesamben because the school has a unique morphology. The school is located on slope areas, so it requires more ability to visualize and sketches the schools than other schools which are located in flat areas. The samples are students of grade 10 and grade 12 who taking the same basic in mapping competence. The results of the mental map study are grade 12 scores better than grade 10 . Students of grade 12 have been longer experiencing the school environment which influences the research results. They have more ability to explore information about the conditions of the school environment.
\end{abstract}

Keywords-Mental mapping, school environment

\section{INTRODUCTION}

The spatial pattern can be interpreted as the specific spatial distribution of the geosphere phenomenon in the earth's surface (Yunus, 2010) . Geosphere phenomenon distribution varies depending on the characteristics of the region.
Geosphere phenomenon, when viewed from the formation process, can be divided into natural phenomena, artificial phenomena, and Artificio-natural phenomena (Yunus, 2010). Natural phenomena are formed from natural processes e.g. rivers, mountains, and sea. The artificial phenomenon is a human creation phenomenon such as roads, buildings, and neighborhoods. Artificio-natural phenomenon is a combination of both natural and artificial phenomenon for example cave settlements

Geosphere phenomenon assesses from the spatial expression can be divided into the physical and non-physical phenomenon (Yunus, 2010). Physical phenomenon indicates a form that can be touched physically such as buildings and roads. Non-physical phenomenon indicates a form which can't be physically touched such as culture, religion, language, and education. In this study, geosphere phenomenon is a physical phenomenon such as the depiction of buildings distribution in the school environment.

Geosphere phenomenon on earth's surface is unevenly distributed. The design of the distribution is known as spatial patterns. To be able to know the form of the object or geographic phenomena distribution, students should be able to organize information or spatial knowledge obtained for example places, buildings, natural objects, or social environment. Furthermore, students can use the information to learn about kinds of phenomena and provide solutions to problems that occur.

Comprehending the spatial patterns is a crucial and basic skill in geography. This determines further comprehension of spaces such as structure, processes, interactions, comparative and spatial development trend. Knowing the locations and characteristics of people, places, and environments is a Necessary precursor to geographic learning and thinking (National Geographic, 2012). One of the tools that can be used to determine the understanding of spatial patterns is by using a 
mental map (Nishimoto, 2012). In addition to understanding the spatial patterns, mental map as well as an indicator to measure how well students understand the characteristics of the environment (National Geographic, 2012).

A mental map is a personal visualization of spatial information. Mental mapping is cognitive or mental abilities that enable us to collect, organize, store, recall, and manipulate information about the spatial environment (Schenk, 2013). In other words, it's a map inside our own mind. The mental map reflects the knowledge and individual experiences. Sometimes mental maps are inaccurate due to the person's perceptions, inexperience, or lack of knowledge. We can develop our mental maps through learning (from the teacher or media) and add personal experiences. This experience can be done either directly (such as travel) or indirectly (such as looking at other maps).

Mental map advantage for the teacher does not mostly lie in the map itself but lies in the perception of the people who make it. The reason mental map depiction is not only to generate the map but also to reveal things about the perception of the person who makes it. "The advantage of mental map depiction is located on interpretation and analysis to suggest something about the behavior and activities within the specific environmental and spatial context" (Stoltman in Snaf, 1999).

For the students, the benefit of the mental map lies in its function as an activity that hone creativity. There is no exactly same mental map and demonstrate environmental attributes with the relatively similar locations. Teachers can use a mental map for diagnostic (perception, representation, and learning) and informative purpose (the location information and the focal point of the neighborhood that may be less familiar to them. One of the important aspects of the mental map is the comparison between the mental maps that students made and real maps (existing) that they will use for further learning. Nowadays the use of complete mental map at school is still quite rare. When teaching, teachers at schools only provide the concept of maps and or how to read the maps.

Good understanding of environmental characteristics through observation and analysis will assist students in problem solving and decision solving. Therefore, the mental map is a basic ability in which students should be owned. The perception or mental image of the world that is held by individuals is at the root of all studies of perception conducted by geographers (Bordessa in Graham, 1976). Knowledge of deeper studies of students' mental map is very important. It is because the mental map can be used as a reference in determining the methods and strategies in the next geography lesson. Besides, mental map can also be used as the basis of analysis of spatial understanding of students about the social and physical environment both locally and globally.

\section{METHOD}

This study uses the quantitative approach with survey method. The survey was conducted in SMAN 1 Kesamben,
Blitar Regency, because of the school's unique morphology. The school is located on hillside areas that need more ability to visualize sketches of the schools than other schools that are located in flat areas. The samples are students of grade 10 and grade12 IIS (Social Sciences) who undergo the same basic competence (mapping). The number of samples in this research is 210 students consisting of grade 10 as many as 105 and grade 12 as many 105 . The study was conducted during the months of August-September 2016. This research uses descriptive analysis. For criteria students mental map uses gradeification scores as follows:

TABLE 1. GRADEIFICATION OF STUDENTS' MENTAL MAP

\begin{tabular}{|c|c|}
\hline Score & Criteria \\
\hline $13-16$ & Very good \\
\hline $9-12$ & Good \\
\hline $5-8$ & Less \\
\hline $1-4$ & Very less \\
\hline
\end{tabular}

\section{FINDING AND DISCUSSION}

In general, students ability in mental map comprehension is based on the criteria gradeification of mental abilities folder. Scores are included in the good gradeification. It can be observed from the average score of the mental map which grade 10 and 12 Social Sciences (IIS) has created as listed in the following table.

TABLE 2. EVERY INDICATORS OF AVERAGE SCORE AND STUDENTS' MENTAL MAP SCORE

\begin{tabular}{|c|c|c|c|c|c|c|}
\hline \multirow[t]{2}{*}{ Grade } & \multicolumn{4}{|c|}{ Each Indicator Assessment average score } & \multirow{2}{*}{$\begin{array}{c}\text { Average } \\
\text { total score }\end{array}$} & \multirow{2}{*}{$\begin{array}{c}\text { Average } \\
\text { Score }\end{array}$} \\
\hline & $\begin{array}{l}\text { Room/Building } \\
\text { Completeness }\end{array}$ & $\begin{array}{c}\text { Space / } \\
\text { Building } \\
\text { Identity }\end{array}$ & $\begin{array}{c}\text { Focus } \\
\text { orientation }\end{array}$ & $\begin{array}{c}\text { Space/ } \\
\text { Building } \\
\text { Proportion }\end{array}$ & & \\
\hline $\mathrm{X}$ IIS & 3.371 & 2.875 & 2.855 & 1,752 & 10.854 & 66.287 \\
\hline XII IIS & 3.740 & 3.308 & 2.672 & 2.079 & 11.800 & 73.773 \\
\hline
\end{tabular}

In addition to the findings above, there are other findings which are the better students get to know their environment, the better mental maps they create. It can be observed of 12grade scores which in general is better than grade 10.The results are matched with the research of Kum\&Ujang (2012) who found that older people can depicture fuller sketch.

The mental condition of grade X and XII can be observed from the total score. Grade X scores of 10.85 , while grade XII scores of 11.80. These students' mental map, in general, can be categorized as good (Table 1). Both internal and external factors can be the main cause by the mental condition. The internal factors include the ability to remember and space abstraction capabilities, while the external factors are the clustered schools' spatial (Iskandar, 2012).

Students' ability to remember is very supportive in the formation of their mental map. Students receive environmental stimuli in the form of information about the condition of the school. The information obtained will be studied in their 
thinking. The process is known as "encoding" and occurs in the cortex system. After that, the information is stored in their memory in "hippocampus". The information about the school environment will be displayed as a depiction of mental map. The process of mental map formation can be viewed in picture 1 .

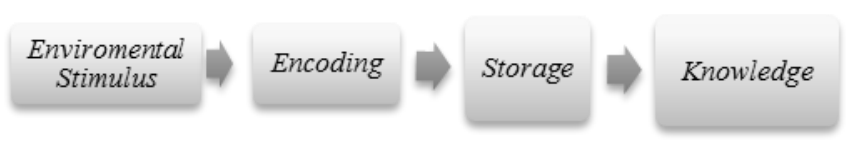

Fig. 1. Stages in Recall

The better the students' memory about the school environment will provide them with better mental map depiction. The memory is influenced by the interval of the interaction of students with school experience (Kum, TL \& Ujang, N., 2012; Blades, 1990). This leads to grade XII have better mental map depiction of the school than grade $\mathrm{X}$.

The good ability of abstraction space of a person will be able to create a good mental map because the mental map is closely related to spatial intelligence. One component of spatial ability is an abstraction of space. Spatial intelligence is a combination of various abilities: to visually perceive the world, to perform transformations based upon one's initial perception, and to recreate aspects of one's visual experience (Sarno, 2004). Intelligence is a congenital factor; nevertheless, exploration experience to the surrounding environment affects that intelligence. Students have been making observations indirectly by way of interacting with the environment every day. A person's cognitive map, or knowledge of large-scale space, is built up from observations gathered as he travels through the environment (Kuipers, 2005). Therefore, they are very familiar with the condition of their school which then resulting in a good mental map.

In addition to internal factors of the ability to remember and abstraction of space, there are also external factors that also affect the results of a good mental map. The external factor is the arrangement of space. Basically, the mental map is the result of two processes between the observer and the environment. The environment gives the impression and the emotional bond which is different in each person. Therefore, in general, a good environment according to Lynch (1960) must satisfy two conditions namely imageability and legibility. Imageability is the ability to give the impression while legibility is the ease to be understood or imagined and organized into a coherent pattern.

To produce an environment that has the necessary legibility and imageability requires good environmental or room planning. One technique that can be used is clustering (Iskandar, 2012). This also applies to the school environment. The arrangement of space in high school where the research took place has been arranged according to function, such as grouping grade rooms X, XI, XII, and administration rooms. This technique can help students remember and behavior of citizen interaction with the environment becomes efficient school. The ease of remembering process will be easier to form a mental map (Iskandar, 2012).

\section{A. Room / Building Completeness}

Completeness indicators score of the building on IIS grade $\mathrm{X}$ is 3.371 and grade XII IIS scores 3.740. The data shows that scores of buildings completeness XII IIS grade are better than the grade X. In general for the completeness of building good indicator of grade XII is better than grade X. They were able to depict the school building or a complete space. Compared with other indicators, the students' scores on this indicator are the best. It is because students already familiar with the school environment, such as the layout and the number of the building even though they do not fully comprehend the rooms' detail.

In creating a school mental map, the students describe the shape and layout of the building space in a more orderly than the original. As aforementioned above that the school is located on the uneven hillside, so that the arrangement of buildings and schoolrooms is also irregular. Students have a tendency to create images/thoughts about the forms of the regular geography of the real condition (Solso, 2001). In addition, students also make their grade room environment as a starting point or early depictions of mental map. This corresponds with the results of several studies that to organize spatial information, people tend to use landmarks as cognitive reference points (Tversky, B., 1992; Lynch, 1960; and aqli, W., 2004). For example, when asked where we live, we often say close the nearest landmark or when giving direction, we often start with a nearby landmark and then give a detailed route.

\section{B. Identification of Space / Building}

The average score that the students obtained of space/building indicator identity is 2.875 to 3.308 for grade $\mathrm{X}$ and grade XII. This score is lower than the indicator of the completeness of the building/room.It means that in mental map abstraction, there are some pictures of the building or space in the school in which the identity is less true or not even given. The main cause is the change of function space or building at the school in recent years, the addition of a building or space for an ongoing process of development and lack of sensitivity to the environment of the school.

Besides the human brain is actually have more ability to process visual information in the form of data than verbal data. This causes human to easily remember a face than others name.Compared to other biographical information, a person's name is more difficult to learn and remember (Cohen, G. 1990; Harris, DM \& Kay, J., 1995). Similar to the case, students also easier to remember visual building or space than the name or identity of the room/building. The ability to remember identities of the space will also be even more difficult due to frequent changes of use or increase in space. 


\section{Focus Orientation}

The depiction of the cardinal directions orientations (north, south, east, and west) on students of grade X sketches is 2.85 better than XI grade by 2.67. Grade X is better than grade XII because they just attend the Student Orientation Period (MOS). During the student orientation, they have introduced school environment including orientation. Nonetheless, there are students who do not include the direction and also mistake in specifying the direction. Based on the principle orientation, north is at the top. It is also commonly used by mapmakers. Mapmakers have traditionally used horizontal and vertical to code the canonical world Reviews directions of north-south and east-west (Tversky, B., 1981).

The results show that students describe the north to the right, left, or down. This condition can occur because of their lack of knowledge of the map. They do not understand that the standard presentation of orientation, north showed an upward direction. In addition, they describe the orientation in accordance with the perception of the local environment. When they draw a school sketch, they do not use knowledge maps but using the existing perception of orientation in their minds. Internal evidence from the map sketches supports the claim that the sketches were drawn from subjective constructions of local environments, rather than from memory of previously learned maps. (Tversky, B., 1981).

In addition to knowledge maps, drawing orientation is also affected by the mental rotation. The ability to transform the rotation direction of the real environment and the map is very important. This capability is part of spatial intelligence. In spatial intelligence, there are two important components in forming the mental rotation, namely, orientation and representation. Orientation is necessary to live in a spatial environment and to perceive images of the world, while representation is necessary to make maps, photos, and descriptions, therefore, the two abilities develop cognitive mapping skills and the specific capacity to understand the surrounding geographical environment and to study it (Sarno, 2004). If someone has a good ability in the mental rotation then he will be able to describe the directions exactly so the mental map is brilliant. This is in matched with the opinion of Palermo (2008) which states that we found that the ability to form a cognitive map was related to the specific ability to perform mental rotations.

\section{The Proportion of Space / Building}

Indicators Proportion of space/building has the lowest score compared to other indicators. This happens both in grade $\mathrm{X}$ and grade XII, although grade XII still had a higher score than the grade of Grade X. Grade X had an average score of 1.752 while grade XII had an average score of 2.079. The low score on this indicator is influenced by the situation and relative location of the room or building which the students remembered. In drawing a mental map, the students only consider the situation or the location of the building to another. They do not pay attention to details and the size of the actual distance. This leads to distortions both distances and sizes. We relate figures to referents, either on the same level of analysis, such as reference points or other figures, or at a superordinate level of analysis, such as reference frames or hierarchical category, and then remember the figures as closer to and / or more aligned with Reviews their referents (Tversky, B., 1992).

\section{CONCLUSIONS AND SUGGESTIONS}

Based on the result, the study concluded that student's mental map in high school is considered quite well. It can be observed from the average score of mental map of grade $\mathrm{X}$ is 66.287 and XII IIS is 73.773. Both internal and external factors influence the overall scores. Internal factors include the ability to remember and abstraction of space. The external factor is the arrangement of space in the school environment. Based on the result, authors suggest:

- The mental map study is best not only describes the school environment but also illustrates the wider area such as a city, province, country and the world.

- Students need to be given an exercise to depict a map in order to improve spatial intelligence.

- Learning geography should be done not only in the grade room but also outside the grade room, as and the introduction to the school environment and the surrounding area.

\section{REFERENCES}

[1] Aqli, Wafirul, 2004, "Identification of the quality of the region through cognitive mapping Case study: white cempaka central region."

[2] Blades, M, "The Reliability of Data Collected From Sketch Maps", Journal of Environmental Psychology, 1990 (10), 327-339, 1990

[3] Cohen, G, 1990,"Why is it difficult, to put names to faces?" British Journal of Psychology, 1990 (81): 287297, [web log post], Retrieved from http://people.westminstercollege.edu.

[4] Graham, Elspeth, 1976, "What is a Mental Map ?". Area Journal, Vol 8. No. 4: 259-262, [web log post], Retrieved from www.jstor.org/stable/20001137

[5] Harris, DM \& Kay, J, 1995, "I Recognize your face but I can not remember your name: Is it Because names are unique?", British Journal of Psychology, 1995 (86): 345 358, [web log post], Retrieved from www.angelfire.compsylearning_faces2

[6] Iskandar, Zulrizka, 2012, "Environmental Psychology Theories and Concepts," PT. Refika Aditama Kuipers: Bandung, Benjamin, 2005.

[7] Kuipers. 2005, "Modelling Spatial Knowledge," [web log post], Retrieved from www.ijcai.org/Proceedings/77-1/Papers/046.pdf

[8] Kum, TL \& Ujang, N, 2012, “The Application Of Mental Mapping Technique in Identifying the Legible Elements Within Historical District of Kuala Lumpur City Centre," Alam Cipta . Vol 5 (1): 55-62.

[9] Lynch, K, 1960, “The Image of the City," Harvard University Press: Massachusetts.

[10] National Geographic, 2012, "How to use mental maps to organize information about people, places, and environments in a spatial context," [web log post], Retrieved from http://nationalgeographic.org/standards/national-geographystandards $/ 02 \%$.

[11] Nishimoto, S, 2012, "Evaluating Mental Maps," Thesis, (Unpublication), Illinois: University of Oregon 
[12] Palermo, L.dkk, 2008, "Mental imagery skills and topographical orientation in humans: a correlation study. Behavioural Brain Research," [2008,192(2):248-253], [web log post], Retrieved from http://europepmc.org/abstract/med/18502521

[13] Peter Lunt, 2009, "Stanley Milgram: Understanding Obedience and its Implications," London: Palgrave Macmillan.

[14] Sarno,Emilia, 2004, "Spatial intelligence and geography," [web log post], Retrieved from www.siue.edu/ Geography /Online/Sarno08.doc

[15] Schenk, Frithjof Benjamin, 2013, "Mental Maps: the cognitive mapping of the continent as an object of research of European history," [web log post], Retrieved from http://ieg-ego.eu/schenkf-2013-en

[16] Snaf, H.R, 1999, "College Students' cognition of the Arab World Map,” Geo journal, Vol. 23: 282 286, [web log post], Retrieved from. http://link.springer.com/article/10.1007/BF00204845

[17] Solso, R.L, 2001, “Cognitive Psychology,” Sixth edition, Allyn \& Bacon

[18] Tversky, B, 1992, "Distortions in Cognitive Maps. Geoforum," Vol. 23 (2): 131-138, [web log post], Retrieved from https://www.tc.columbia.edu/faculty/bt2158/facultyprofile/files/1992_Tversky_Distortionsincognitivemaps.pdf.

[19] Tversky, B, 1981, "Distortions in Memory for Maps," Cognitive Psychology 13, 407-433(1981), [web log post], Retrieved from http://www.tc.columbia.edu/.../1981_Tversky_Distorsionnm.

[20] Yunus, Sabari Hadi, 2010, "Metodologi Penelitian Wilayah Kontenporer," Pustaka Pelajar: Yogyakarta. 